\title{
Differences in Interproximal and Occlusal Tooth Wear Among Prehistoric Tennessee Indians: Implications for Masticatory Function
}

\author{
ROBERT J. HINTON \\ Department of Anatomy, and Center for Human Growth and Development, \\ The University of Michigan, Ann Arbor, Michigan 48109
}

KEY WORDS Interproximal tooth wear, Masticatory function, Amerindians, Tennessee Valley

\begin{abstract}
Breadth of the interproximal wear facet between lower P2 and M1 and between lower M1 and M2 was measured in human skeletal samples representing the Archaic, Woodland, and Mississippian periods of Tennessee River Valley prehistory, with the aim of assessing relative magnitudes of applied masticatory forces. When stratified by level of occlusal wear, mean interproximal facet breadth was consistently larger in the Archaic sample than in the Mississippian sample, with the Woodland sample intermediate. An analysis of covariance demonstrated that there was significant $(p \leq 0.01)$ differences in facet size among the three groups even when differences in crown breadth were taken into account. Similar results were obtained in regressions of facet size on chronological age $\mathrm{Ar}$ chaic larger than Mississippian at $p \leq 0.01$ ). Since rate of occlusal wear appears to be somewhat greater in the Archaic sample than in the later samples, the differences in interproximal wear are probably underestimated. It is suggested that the high levels of interproximal wear in the Archaic are indicative of the large occlusal forces and repetitive chewing required to masticate a diet of seeds, wild plant foods, and small animals, for which prior preparation (e.g., grinding, cooking) was minimal or nonexistent (as indicated by paleofecal samples). The lower amounts of interproximal wear observed in the Woodland and Mississippian samples imply considerable reductions in strenuous mastication, perhaps due to the widespread adoption during these periods of pottery and the earth oven, together with ethnographically-documented techniques of food preparation that transformed most foods to a soft consistency.
\end{abstract}

Numerous attempts have been made to utilize dental wear as an indicator of diet or tooth use in aboriginal human groups. The mixed success achieved by these efforts is in part a reflection of the complexity of the phenomena under investigation, encompassing both the intricacies of the masticatory process itself and the multifaceted nature of the cultural and environmental contexts in which mastication takes place. Many studies have concentrated on the gradual wearing away of the occlusal surfaces of teeth, but considerably less attention has been devoted to the development of flattened facets or polished planar areas at the points of contact between adjacent teeth. These facets (interproximal wear as op- posed to occlusal wear) also involve a wearing away of the tooth substance, but on the mesial and/or distal aspects of the crown.

Interproximal wear is generally acknowledged to result from the differential movement of teeth during mastication. The amount of interproximal wear that occurs is thought to be dependent upon the magnitude of the force exerted upon a tooth by the teeth distal to it in the tooth row, designated the mesial force vector (Picton, 1962) because of the direction in which it acts, and upon the frequency with which such force is applied. Wolpoff (1971) has suggested that, while multiple factors may

Received August 18, 1980; accepted September 1, 1981. 
play a part in the production of the mesial force vector, the most important single factor is probably the mesial angulation of the teeth themselves (Dempster et al., 1963; Kraus et al., 1969). In this sense, then, the mesial force vector is simply the mesially-directed component of the bite force vector - that is, that fraction of the bite force that acts to press the teeth together along the tooth row. Wolpoff (1971) further asserts that it is this component of force, in combination with the lateral or sideways motion of individual teeth with respect to each other, which over time results in the production of an interproximal wear facet between adjacent teeth. This contention, which has longstanding antecedents in orthodontic clinical practice (cf., Brodie, 1934; Dewell, 1949; Moyers, 1973), is supported by several lines of evidence. For example, ample evidence attests to the mobility of individual teeth during function (Picton, 1962, 1964), and to the effects of repeated biting and clenching for increasing this mobility, especially the amount of mesial tilt (Picton, 1962; O'Leary et al., 1967). Moreover, photoelastic simulation studies lend credence to the view that, for a bite force of specified magnitude and direction, mesial tilting of teeth is associated with a horizontal bite force component of variable but large magnitude (Ward, 1974). Finally, it is now clear, based on both force transducer (Graf, 1975) and bone strain (Hylander, 1979) measurements, that a lateral component of the bite force is present during molar chewing. While the role of the mesial force vector as the primary cause of tooth migration has been questioned (Moss and Picton, 1970; Picton and Moss, 1973, 1974), it is nevertheless very likely to be one of the main determinants in this multifactorial process (Picton and Moss, 1980; Van Beek and Fidler, 1977).

Based on the causative model just outlined. extensive interpopulational variation in the amount of interproximal wear might be expected, with the greatest wear in those human groups for which ethnographic accounts and comparative bite force data document the habitual practice of vigorous mastication. $\mathrm{Al}$ though systematic comparisons have not been performed, there is reason to suspect that considerable variation does indeed exist among human groups; e.g., Australians apparently exhibit substantially greater interproximal wear than Europeans (see Moss and Picton, 1967; Wolpoff, 1971). Because of its functional etiology, the rate and amount of interproximal wear should be directly related to the magnitude and frequency of forces applied during mastication. On the other hand, occlusal wear rates are not only influenced by both these factors, but also by the abrasive properties of the food consumed together with associated dietary grit (Wolpoff, 1971). As such, the study of interproximal wear offers the possibility of insights into masticatory function and food preparation that may be obscured by examination of occlusal wear data alone. It is the purpose of this report to present data on interproximal and occlusal tooth wear in a temporal series of American Indian populations which once inhabited the valleys and adjacent highlands surrounding the Tennessee River. These data will then be used to elucidate aspects of cultural history for the prehistoric groups in question and to evaluate more completely the causative model for interproximal wear.

\section{MATERIALS}

The samples included in this study are composed of human skeletal remains representing each of the three major chronological periods in Tennessee Valley prehistory (Table 1). Spanning about 7500 years (ca. $6000 \mathrm{BC}-\mathrm{AD} 1550$ ), they encompass a gradual transition in subsistence practices from a fully hunting and gathering lifeway to a primary dependence on maize agriculture. ${ }^{1}$ The Archaic is characterized by a focus on the hunting of a wide variety of game, fishing, and collection of aquatic resources (e.g., mussels), as well as the utilization of various nuts, seeds, and wild plant foods (Lewis and Lewis, 1961; Faulkner, 1977). The sites comprising this sample can be temporally subdivided into Middle Archaic (Eva I and II at 6000-3000 BC) and Late/Terminal Archaic (Eva III, Cherry and Ledbetter Landing at $2500-500 \mathrm{BC}$ ). The Woodland subsistence pattern involved a continued reliance on hunting and collecting (Crites, 1978; Faulkner et al., 1976; Faulkner, 1977) together with the incipient cultivation of the sunflower, squash, and maize (Crites, 1978), and is represented by remains from several sites of Late Woodland age (750-1150 AD). The Mississippian sample, composed of individuals from a single Late

\footnotetext{
'These samples are largely similar to those utilized in a previous study (Hinton et al., 1980), of which the present investigation is an outgrowth. Additional details concerning cultural contexts of the samples can be found in Smith et al. (1980).
} 
TABLE 1. Composition, dates, and sizes of the samples

\begin{tabular}{|c|c|c|c|c|}
\hline Sample & Sites & $\mathbf{N}$ & Dates & References \\
\hline Archaic & $\begin{array}{l}\text { Eva }(6 \mathrm{BN} 12) \\
\text { Cherry (84BN74) } \\
\text { Ledbetter Landing (9BN25) }\end{array}$ & 106 & $6000-500 \quad B C$ & $\begin{array}{l}\text { Lewis and Kneberg (1959); } \\
\text { Lewis and Lewis (1961); } \\
\text { Magennis (1977); Bowen }(1975,1979)\end{array}$ \\
\hline Woodland & $\begin{array}{l}\text { Hiwassee Island (46MG31 and 42MG31) } \\
\text { Alford (4RE4) } \\
\text { Wilson (23RE6) } \\
\text { Hampton (89RH41 and 93RH41) } \\
\text { Montgomery (76RE8 and 77RE8) }\end{array}$ & 107 & $700-1150 \mathrm{AD}$ & Lewis and Kneberg (1946) \\
\hline Mississippian & Toqua (40MR6) & 118 & $1300-1550 \mathrm{AD}$ & Schroedl and Polhemus (1977) \\
\hline
\end{tabular}

Mississippian site ${ }^{2}(1300-1550 \mathrm{AD}$ ), is exemplary of an emphasis on food production, supplemented by hunting and collecting (Lewis and Kneberg, 1946).

\section{METHODS}

In each individual, breadth of interproximal wear facets, mesiodistal and buccolingual crown diameters, and severity of occlusal wear were recorded for the lower right first and second molars. If these teeth were missing, teeth on the left side were analyzed. Breadth of the interproximal wear facet was measured in two locations (Fig. 1): between the second premolar and first molar and between the first and second molars. Since this technique cannot fully take into account instances of S-shaped or wavy interproximal contact, it is conservative in nature (i.e., underestimates the facet breadth). Mesiodistal and buccolingual dimensions were taken on the lower M1 and M2 following the method of Goose $(1963)^{3}$, in order to permit an assessment of the influence of gross tooth size on wear facet breadth. Finally, severity of occlusal wear was scored using an eight-level ordinal system adapted from Molnar (1968, 1971a,b; see Hinton, 1981a,b for previous uses of this wear code). These data permitted the comparison of interproximal wear in subsamples having the same level of occlusal wear, while enabling a rough assessment of relative occlusal wear rates among the samples to be made.

Sex and age were determined postcranially for each specimen by Magennis (1977) for the Archaic material (with the exception of Ledbetter Landing), by Parham (n.d.) for the Mississippian sample, and by the author and/or laboratory personnel for the Ledbetter Landing and Woodland material. Due to poor preservation in the Woodland sample, a majority of the specimens used could not be sexed; similarly, no age determinations were available for either Ledbetter Landing (Late Archaic) or Woodland material. Similar criteria, primarily pubic symphyseal morphology and epiphyseal union (in young adults), were employed for age assessment in both Archaic and Mississippian samples. Dental (occlusal) attrition was not used as a criterion for aging, except occasionally in very old individuals. The midpoint of the estimated age interval, which varied in size from 5-10 years in most instances, was taken as the specimen's age. While this procedure undoubtedly involves some error, it was judged preferable to the lumping of individuals into broadly. defined age intervals and permitted the utilization of regression techniques on the age data.

\section{RESULTS}

When stratified by occlusal wear level ${ }^{4}$, mean interproximal wear facet breadths show appreciable intergroup differences, and occur in a clearly-defined hierarchy of size (Table 2; Fig. 2 and 3). In every instance except one, the Archaic mean interproximal wear is greater (albeit not appreciably so for P2M1 facet

2The human remains are derived from a site belonging to the Dallas focus, a prehistoric manifestation of the Late Mississippian. A possible exception to this statement concerns six individuals, who may be attributable to the protohistoric Cherokee of the area (R. Polhemus, personal communication). However, in view of the small number and temporal proximity of the putative Cherokee burials relative to the Dallas burials, the six individuals were retained in the sample. As sessments of interproximal and occlusal wear in these specimens indicate no significant differences from those of the remainder of the sample.

${ }^{3}$ For further details of measurement technique for tooth size, see Hinton et al. (1980).

${ }_{4}^{4}$ or purposes of analysis, facet breadths between $\mathrm{P} 2$ and $\mathrm{M} 1$ were compared relative to occlusal wear on $\mathrm{M} 1$, where the primary component of the mesial force vector originates. Similarly, facet breadths between $M 1$ and $M 2$ were compared relative to occlusal wear on $M 2$, the primary source of the mesial force vector for production of this facet. 

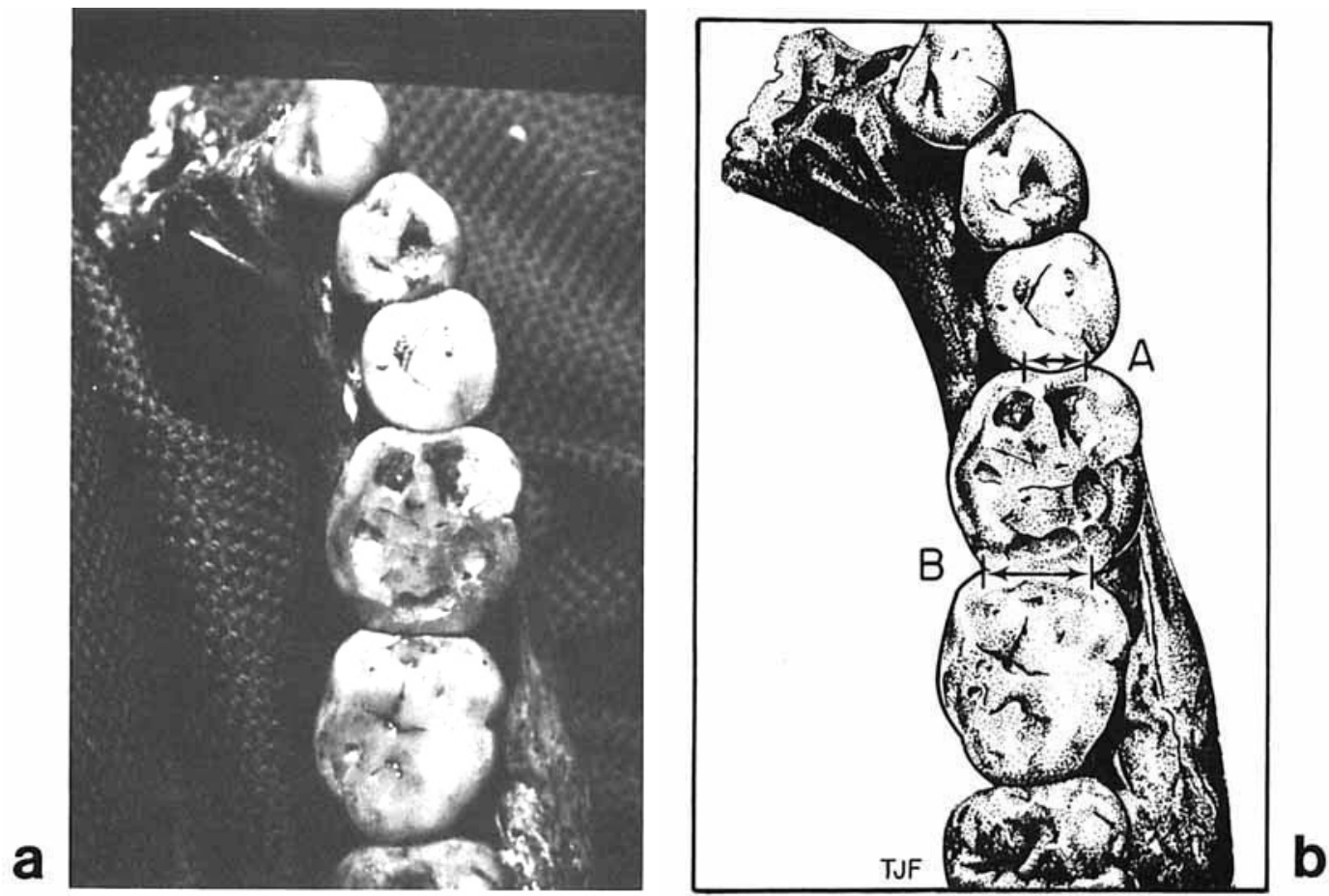

Fig. la. Interproximal wear facets in specimen $6 \mathrm{BN} 37$, a male individual from Eva Archaic site. Fig. 1b. Drawing of Figure la showing measurement of interproximal wear facet breadth between $\mathrm{P} 2$ and $\mathrm{M} 1$ (distance $\mathrm{A}$ ) and between $\mathrm{M} 1$ and $\mathrm{M} 2$ (distance B).

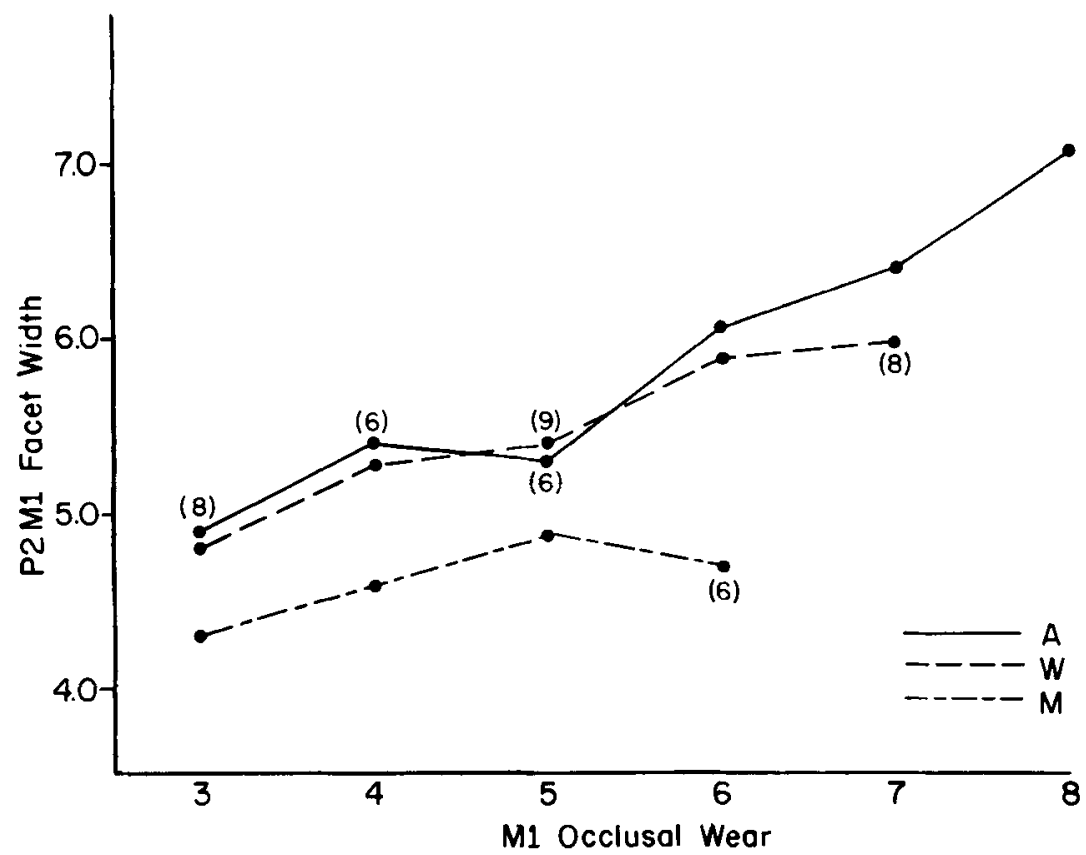

Fig. 2. Mean interproximal wear facet breadth betwen $\mathrm{P} 2$ and $\mathrm{M} 1$ as a function of occlusal wear level on $\mathrm{M} 1$ in Archaic, Woodland, and Mississippian samples. 


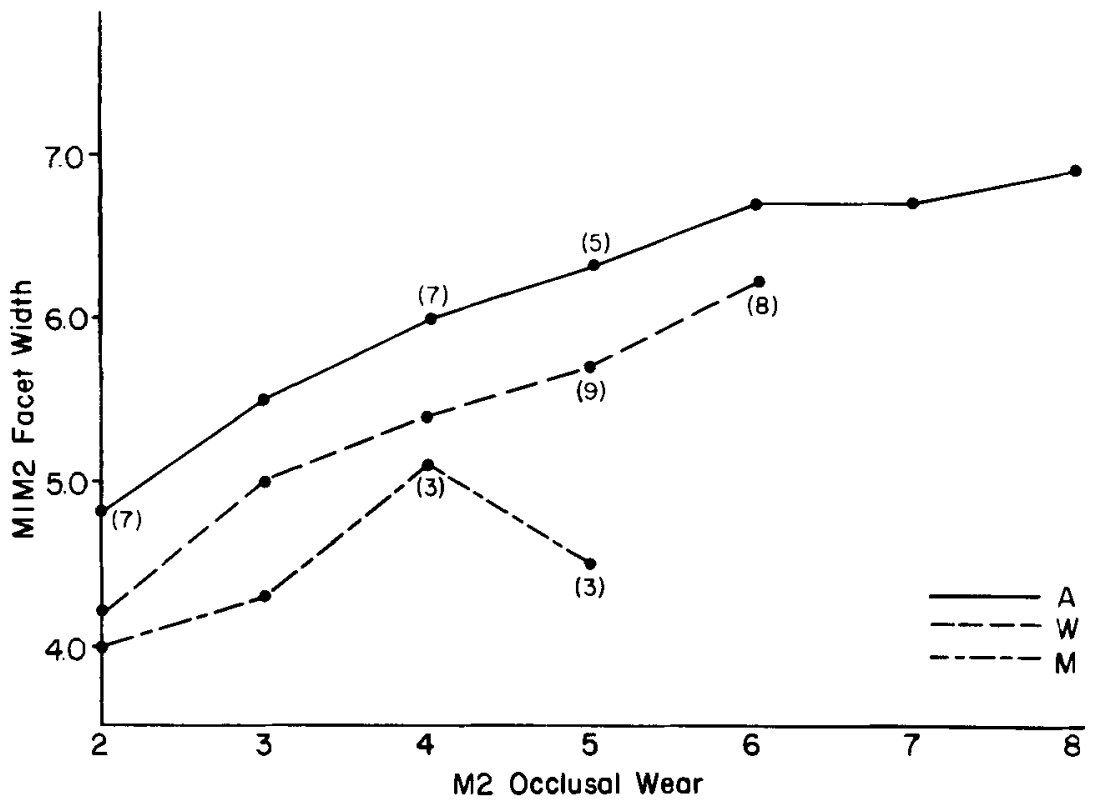

Fig. 3. Mean interproximal wear facet breadth between M1 and M2 as a function of occlusal wear level on M2 in Archaic, Woodland, and Mississippian sample.

TABLE 2. Mean interproximal wear facet breadth stratified by level of occlusal wear

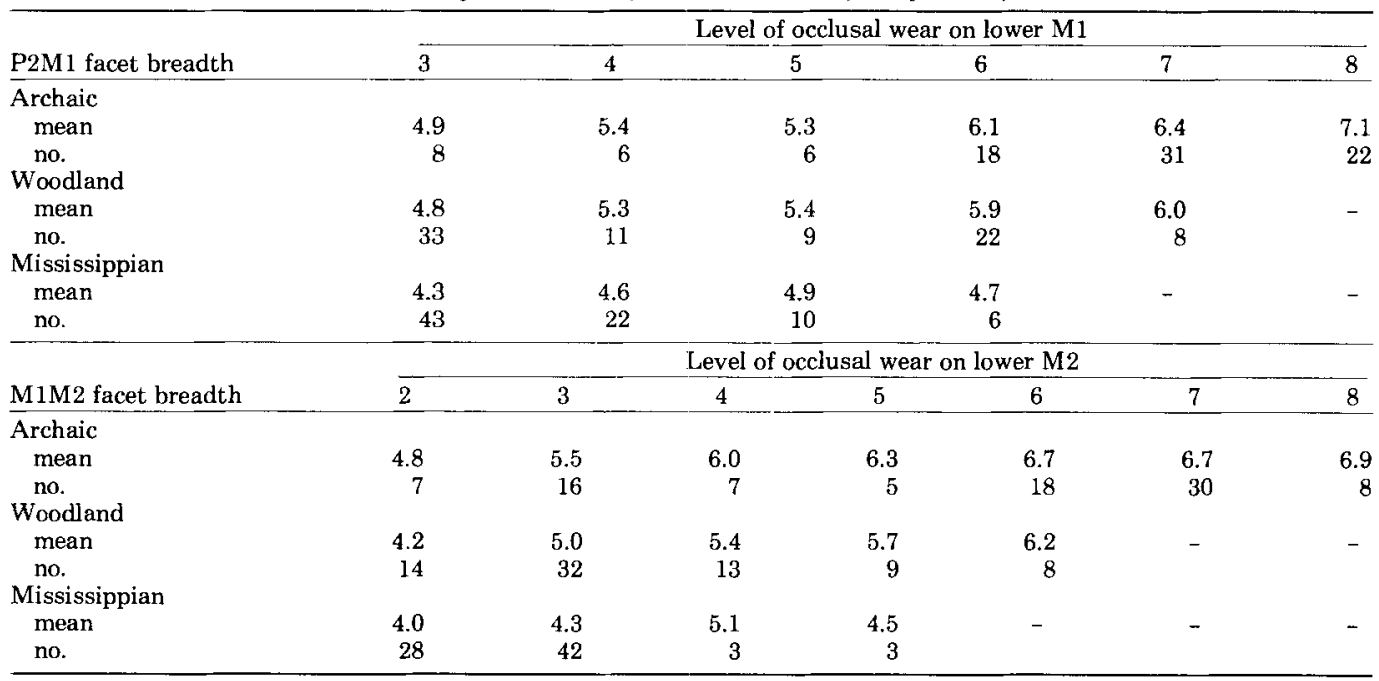


breadth) than that of the Woodland. In every instance, the Woodland mean interproximal wear is greater than the Mississippian. ${ }^{5}$

Since the samples differ in tooth size (Hinton et al., 1980; Smith et al., 1980), consideration was given to the possible effects of overall tooth size on size of the interproximal wear facet. Calculations of Pearson's product moment correlations between crown dimensions and interproximal facet size (Table 3) demonstrated a positive relationship between facet size and crown breadth and a negative relationship between facet size and crown length. Since changes in crown length are presumably indicative of similar phenomena as interproximal facet breadth, they were not investigated further. Considered by itself, crown breadth is a significant but weak $\left(\mathrm{r}^{2}=0.38-0.45\right)$ predictor of facet size within groups. However, analysis of covariance with group and occlusal wear as factors and crown breadth as the covariate indicates that occlusal wear is important in the prediction of facet breadth even when crown breadth is taken into account (Table 4). In the full model, interactions involving the covariate and the group and/or occlusal wear factors were of minimal or no significance. The second step of the analysis of covariance (ANOCOVA model omitting interaction terms) demonstrates that significant differences exist for both P2M1 and M1M2 facet size among the three groups (see partial sums of squares, F and $p$ values for group in Table 4), and among the four occlusal wear levels (although this was perhaps to be expected). Pairwise t-tests provide assessment of differences in facet size between each pair of groups (Table 5).

Multiple linear regressions ${ }^{6}$ of wear facet size on age in the Archaic and Mississippian samples (ages were not available for the Woodland sample) provide similar indications of intergroup differences in interproximal wear (Table 6). Intercepts between the two groups are significantly different for both P2M1 and M1M2 facet breadths, but the slopes of their regression lines are not.

\section{DISCUSSION}

The preceding analyses provide evidence that the magnitude of interproximal wear differs in a consistent and marked fashion between three temporally contiguous and genetically similar human groups. Specifically, the Archaic sample displays a significantly greater amount of interproximal wear than do the Woodland and Mississippian samples at identical levels of occlusal wear, a result which is borne out by analysis of covariance and by regressions of facet breadth on chronological age. These results are a confirmation of an earlier suggestion (Hinton et al., 1980:234) that larger occlusal areas, but similar mean breadths, in Woodland molars as compared to Archaic molars, were due to greater interproximal attrition in the Archaic sample. In addition, these data provide some indication that interproximal wear in the Woodland sample may be greater than in the Mississippian, and somewhat less than in the preceding Archaic. Certainly for those levels of occlusal wear (e.g., level 3 on M2, and to a lesser extent level 2 on M2 and level 3 on M1) in which all three samples are of satisfactory size, Woodland means are demonstrably intermediate between the Archaic and Mississippian extremes, a point which merits further study. It is also intriguing that although slopes of the regression lines (rate of interproximal wear) are not significantly different in the Archaic and Mississippian samples (see Table 6), these slopes are in accordance with expectations based on magnitude of interproximal wear: that is, the rate in the Archaic is slightly more rapid.

\section{Effect of rate of occlusal attrition}

Comparison of interproximal wear in subsamples stratified on the basis of occlusal wear level leaves open the possibility that intergroup differences in rate of occlusal wear could account for part or all of the observed interproximal wear differences. Thus, if rate of occlusal wear were more rapid in the Mississippian sample, this could result in comparisons in which the Mississippian subsamples were chronologically younger than their counterparts in the Archaic, thereby explaining, at least in part, the lesser interproximal wear

${ }^{5}$ The decrease in mean interproximal facet breadth in the later $\boldsymbol{\alpha}$ clusal wear levels of the Mississippian sample may represent the effects of loss of adjacent teeth and the consequent diminution of wear facet breadth below the leve] that might occur if the tooth row were intact. This decrease is not seen in the Archaic and Woodland samples, groups in which tooth loss is appreciably less and likely of different etiology. However, comparisons with the Archaic and Woodland groups made at wear levels 2,3 , and 4 should not be affected, since they sample functional ages prior to the time when tooth loss becomes extensive.

6The multiple linear regression model included the dependent variable, facet breadth, and the independent variables, age and group. The two groups, Archaic and Mississippian, were represented in the model by binary combinations of an indicator variable. which allowed the fitting of two regression lines (one for each group) in a single model (Neter and Wasserman, 1974:297-311). 
TABLE 3. Pearson's product moment correlations between crown diameters and interproximal facet breadth

\begin{tabular}{|c|c|c|c|c|}
\hline & M1 breadth & M1 length & M2 breadth & M2 length \\
\hline \multicolumn{5}{|c|}{ P2M1 facet breadth } \\
\hline Archaic & .02 & $-.45 * *$ & & \\
\hline Woodland & $.29 * *$ & $-.26^{*}$ & & \\
\hline Mississippian & $.36 * *$ & -.05 & & \\
\hline \multicolumn{5}{|c|}{ M1M2 facet breadth } \\
\hline Archaic & .07 & $-.47^{* *}$ & $.26^{*}$ & -.21 \\
\hline Woodland & .18 & $-.22 *$ & .19 & -.20 \\
\hline Mississippian & $.25^{*}$ & -.22 & .08 & $-.26^{*}$ \\
\hline
\end{tabular}

*Denotes a correlation significantly different from zero at $\mathrm{p} \leq 0.05$.

**Denotes a correlation significantly different from zero at $\mathrm{p} \leq 0.01$.

TABLE 4. Analysis of covariance: effect of crown breadth, group, and occlusal wear on interproximal facet breadth

\begin{tabular}{|c|c|c|c|c|c|c|c|}
\hline \multirow[b]{2}{*}{ Source } & \multirow[b]{2}{*}{$\begin{array}{l}\text { Degrees of } \\
\text { freedom }\end{array}$} & \multicolumn{3}{|c|}{ Full model } & \multicolumn{3}{|c|}{ Anocova model } \\
\hline & & $\begin{array}{c}\text { Sequential sums } \\
\text { of squares }\end{array}$ & Fvalue & $\mathrm{p}$ value & $\begin{array}{c}\text { Partial sums } \\
\text { of squares }\end{array}$ & $F$ value & p value \\
\hline \multicolumn{8}{|l|}{ P2M1 facet breadth } \\
\hline Ml crown breadth & 1 & 23.21 & 42.00 & 0.0001 & 17.36 & 15.15 & 0.0001 \\
\hline Group & 2 & 82.95 & 75.06 & 0.0001 & 50.82 & 29.56 & 0.0001 \\
\hline M1 occlusal wear ${ }^{1}$ & 3 & 50.82 & 30.66 & 0.0001 & 9.88 & 17.25 & 0.0001 \\
\hline Interaction terms ${ }^{2}$ & 11 & 10.98 & 1.81 & 0.05 & & & \\
\hline \multicolumn{8}{|l|}{ M1M2 Facet Breadth } \\
\hline M2 crown breadth & 1 & 27.72 & 43.77 & 0.0001 & 43.07 & 34.07 & 0.0001 \\
\hline Group & 2 & 135.24 & 106.78 & 0.0001 & 58.44 & 30.82 & 0.0001 \\
\hline M2 occlusal wear & 3 & 58.44 & 30.76 & 0.0001 & 3.30 & 5.22 & 0.0233 \\
\hline Interaction terms & 11 & 3.76 & 0.54 & N.S. & & & \\
\hline
\end{tabular}

In order to avoid cells containing individuals, occlusal wear levels were grouped as follows: M1 wear: 1-3,4,5,6-8; M2 wear: 1-2,3,4,5-8. 'Interactions of crown breadth with group, crown breadth with occlusal wear, and of crown breadth with group and occlusal wear were considered. The interaction of group with occlusal wear was found in a previous analysis to be nonsignificant, and was omitted from the analyses presented above.

TABLE 5. Intergroup comparisons for interproximal facet breadth:

Pairwise t-tests of differences between least squares means

\begin{tabular}{lc}
\hline Comparison & $\begin{array}{c}\text { Simultaneous } \\
\text { p value }^{1}\end{array}$ \\
\hline P2M1 facet breadth & \\
Archaic vs. Woodland & 0.0399 \\
Archaic vs. Mississippian & 0.0003 \\
Woodland vs. Mississippian & 0.0006 \\
M1M2 facet breadth & \\
Archaic vs. Woodland & 0.0003 \\
Archaic vs. Mississippian & 0.0003 \\
Woodland vs. Mississippian & 0.0045 \\
\hline
\end{tabular}

'Significance was determined using the Bonferroni family confidence coefficient, which takes the fact that multiple t-tests are made on the same data into account in assigning $p$ values.

noted in Mississippian individuals. Aside fro the issue of whether such a disparity could account for the magnitude of intergroup differences that exist, investigation of relative rates of occlusal wear among the three samples suggests that the above scenario is likely not the case. First, the median age for individuals at each level of occlusal wear is consistently lower in the Archaic than in the Mississippian (Table 7), implying that occlusal wear occurs at a more rapid pace in Archaic individuals. This view can also be expressed by noting in Table 7 that the time difference in median age between M1 and M2 reaching the same level of wear (level 3) is one year in the Archaic, and 4.5 years in the Mississippian. Although ages in the two samples were assigned by different workers, it is unlikely that any bias in estimation techniques could account for the systematic and appreciable differences in median age that exist between samples at all occlusal wear levels.

A second approach to this problem may be made through use of occlusal wear differentials between $\mathrm{M} 1$ and M2. Within the human species, for groups with similar tooth eruption timings, the difference in wear level between the first and second molars should reflect the rate of occlusal wear - that is, the larger the differential, the greater the rate of wear during the 6-year time period between the eruption of these two teeth ${ }^{7}$ (see Lavelle, 1970; Walker,

\footnotetext{
${ }^{7}$ Although it may be argued with some justification that this "differential" may be of variable magnitude over the functional lifetime of the dentition due to the over-reliance for mastication on M1 during the period of mixed dentition (Taylor, 1963), it is nevertheless a useful, if crude. indicator of relative rate of occlusal wear.
} 
TABLE 6. Regression of interproximal facet breadth on chronological age ${ }^{1}$

\begin{tabular}{|c|c|c|c|c|}
\hline Sample & Intercept & & Slope & \\
\hline \multicolumn{5}{|l|}{ Regression of $\mathrm{P} 2 \mathrm{M} 1$ facet breadth on age } \\
\hline $\begin{array}{l}\text { Archaic } \\
\quad(p=\text { Archaic same as zero })\end{array}$ & 4.11 & $.0001 * *$ & 0.06 & $.0001^{* *}$ \\
\hline $\begin{array}{l}\text { Mississippian } \\
\qquad(\mathrm{p}=\text { Archaic same as Mississippian) }\end{array}$ & 2.93 & $.0135^{*}$ & 0.05 & .8105 \\
\hline Regression of M1M2 facet breadth on age & & & & \\
\hline $\begin{array}{l}\text { Archaic } \\
(\mathrm{p}=\text { Archaic same as zero })\end{array}$ & 4.49 & $.0001 * *$ & 0.05 & $.0001^{* *}$ \\
\hline $\begin{array}{l}\text { Mississippian } \\
(\mathrm{p}=\text { Archaic same as Mississippian) }\end{array}$ & 3.35 & $.0246^{*}$ & 0.03 & .1891 \\
\hline
\end{tabular}

'Similar multiple regressions incorporating crown breadth as one of the independent variables were performed. Although not shown, they demonstrate the minimal ef fect of crown breadth on facet size in comparison to age (partial sums of squares $=17.47$ for age, 5.31 for $\mathrm{MI}$ breadth; 20.99 for age, 1.32 for M2 breadthl.

TABLE 7. Median age at various stages of occlusal wear in Archaic and Mississippian samples

\begin{tabular}{|c|c|c|c|c|}
\hline & \multicolumn{4}{|c|}{ Level of occlusal wear on $\mathrm{M} 1$} \\
\hline & 3 & 4 & 5 & 6 \\
\hline $\begin{array}{l}\text { Archaic } \\
\text { median age (yrs.) } \\
\text { no. }\end{array}$ & 18.0 & 17.5 & 21.0 & $\begin{array}{l}30.5 \\
14\end{array}$ \\
\hline $\begin{array}{l}\text { Mississippian } \\
\text { median age (yrs.) } \\
\text { no. }\end{array}$ & $\begin{array}{l}23.0 \\
43 \\
\end{array}$ & $\begin{array}{l}30.0 \\
22\end{array}$ & $\begin{array}{l}30.0 \\
11 \\
\end{array}$ & $\begin{array}{c}35.0 \\
5 \\
\end{array}$ \\
\hline & \multicolumn{4}{|c|}{ Level of occlusal wear on $\mathrm{M} 2$} \\
\hline & 2 & 3 & & \\
\hline $\begin{array}{l}\text { Archaic } \\
\text { median age (yrs.) } \\
\text { no. }\end{array}$ & $\begin{array}{c}18.0 \\
6\end{array}$ & $\begin{array}{l}19.0 \\
11\end{array}$ & & \\
\hline $\begin{array}{l}\text { Mississippian } \\
\text { median age (yrs.) } \\
\text { no. }\end{array}$ & $\begin{array}{l}21.0 \\
28\end{array}$ & $\begin{array}{l}27.5 \\
42\end{array}$ & & \\
\hline
\end{tabular}

1978). Distributions of the magnitude of the M1-M2 wear differential (Table 8) indicate a considerably higher percentage of individuals in the Archaic sample exhibiting a differential of 2 or 3 levels than in the Mississippian sample, with the Woodland intermediate in this fraction. This disparity is particularly striking for individuals having $\mathrm{M} 1$ wear levels ranging from 4 to 6 (those levels whose scoring is most unambiguously defined-i.e., by specific patterns and extent of dentin exposure - see Hinton, 1981b). In these individuals, the percentage having wear differentials of 2 or more levels is twice as high in the Archaic as in the Woodland, and two-and-one-half times as high as in the Mississippian.

Admittedly, these data are hampered by under-representation of younger individuals in the Archaic sample (Magennis, 1977). They are nevertheless suggestive that, if there is any difference at all in wear rates between groups, it is likely that the rate of occlusal wear is greater in the Archaic sample than in the later groups. Hence, it can be assumed that the levels of interproximal wear observed are, if anything, conservative reflections of intergroup differences, since the Archaic individuals in each comparison are likely about the same age or even younger than their Mississippian counterparts.

Implications for masticatory force application

Based on what is known of the functional etiology of interproximal wear, it is likely that the intergroup differences in interproximal wear are indicative of differences in masticatory force among these groups. Corroboration of this notion can be sought in other features of craniofacial skeletal morphology that have been linked to force generation during mastication. One such feature is the size of the mandibular fossa (Hinton and Carlson, 1979), a structure whose size and shape may represent an accommodation to the size of the mandibular condyle with which it articulates during dental function. That condylar size may reflect the magnitude and frequency of forces applied to it during mastication and/or tooth 
use has been suggested by a number of workers, based on studies in human paleontology (Wolpoff, 1975; White, 1977) and oral anatomy (Watt and Williams, 1951; Barber et al., 1963; Moore, 1965). Certainly experimental studies of condylar growth and development confirm that the condylar cartilage is responsive to varying patterns and intensities of joint reaction forces resulting from dental loading (Simon, 1977; Carlson et al., 1978; McNamara and Carlson, 1979). Whatever the case, there are appreciable differences in condyle and mandibular fossa size among extant and prehistoric human groups (Hinton, 1981c), and these differences are consistent with what is known of tooth use in these groups. Thus, while differences in condyle size are undoubtedly attributable to a multiplicity of factors (e.g., overall cranial size and/or robusticity, genetic influences), the existence of a substantial functional component seems likely. For the American Indian groups in question, data on condyle and mandibular fossa size (Table 9) are in agreement with the trends noted for interproximal wear. The largest mean temporomandibular joint dimensions are found in the sample (Archaic) in which the largest mean interproximal wear facet breadths are noted, with corresponding decreases in TMJ size in groups having less interproximal wear. These trends are present in both males and females, although the number of sexed individuals in the Woodland sample is small; as in the interproximal wear data, the Woodland TMJ dimensions are intermediate between those for the Mississippian and those for the Archaic.

The circumstances of daily living that might have prompted such differences in masticatory force application are far from clear, but some conjecture can be offered based on our knowledge of food habits in these groups. Despite the departure from the Archaic pattern represented by the increasing reliance on cultigens in the Woodland and Mississippian periods, a number of workers have noted the continued utilization of similar plant foods and animal resources as a substantial portion of the diet

TABLE 8. Distributions of M1-M2 occlusal wear differential ${ }^{1}$ in Archaic, Woodland, and Mississippian samples

\begin{tabular}{|c|c|c|c|c|c|c|c|}
\hline \multirow[b]{2}{*}{ Sample } & \multicolumn{6}{|c|}{$\begin{array}{l}\text { Number of individuals having } \\
\text { a wear differential of }\end{array}$} & \multirow{2}{*}{$\begin{array}{c}\text { Percent having } \\
\text { differential of }+2 \text { or }+3\end{array}$} \\
\hline & -2 & -1 & 0 & +1 & +2 & +3 & \\
\hline \multicolumn{8}{|c|}{ Individuals with Wear Levels $3-8$ on M1 } \\
\hline Archaic & 0 & 1 & 34 & 38 & 10 & 6 & 18 \\
\hline Woodland & 1 & 0 & 32 & 34 & 7 & 3 & 13 \\
\hline Mississippian & 0 & 0 & 18 & 43 & 5 & 1 & 9 \\
\hline \multicolumn{8}{|c|}{ Individuals with Wear Levels $4-6$ on M1 } \\
\hline Archaic & 0 & 1 & 6 & 10 & 9 & 4 & 43 \\
\hline Woodland & 1 & 0 & 8 & 19 & 6 & 3 & 24 \\
\hline Mississippian & 0 & 0 & 6 & 21 & 5 & 1 & 18 \\
\hline
\end{tabular}

${ }^{1} \mathrm{M} 1-\mathrm{M} 2$ wear differential was computed as the signed difference between the level of wear on M1 minus the level of wear on the adjacent M2; a positive differential thus implies that $\mathrm{M} 1$ wear is greater than M2 wear. while a negative differential implies the converse.

TABLE 9. Temporomandibular joint dimensions in Tennessee Indians: Size of the mandibular condyle and mandibular fossa ${ }^{1}$

\begin{tabular}{|c|c|c|c|c|c|c|c|c|}
\hline \multirow[b]{2}{*}{ Sample } & \multicolumn{2}{|c|}{$\begin{array}{c}\text { Condylar } \\
\text { length }\end{array}$} & \multicolumn{2}{|c|}{$\begin{array}{l}\text { Condylar } \\
\text { breadth }\end{array}$} & \multicolumn{2}{|c|}{$\begin{array}{c}\text { Condylar } \\
\text { area }\end{array}$} & \multicolumn{2}{|c|}{$\begin{array}{l}\text { Mandibular } \\
\text { fossa area }\end{array}$} \\
\hline & Male & Female & Male & Female & Male & Female & Male & Female \\
\hline \multicolumn{9}{|l|}{$\overline{\text { Archaic }}$} \\
\hline mean & 9.1 & 8.7 & 21.5 & 18.9 & 200.9 & 163.6 & 170.9 & 156.3 \\
\hline no. & 49 & 32 & 31 & 25 & 31 & 25 & 60 & 40 \\
\hline \multicolumn{9}{|c|}{ Woodland } \\
\hline mean & 8.4 & 8.1 & 20.6 & - & 173.3 & - & 161.8 & - \\
\hline no. & 14 & 6 & 11 & & 11 & & 17 & \\
\hline \multicolumn{9}{|c|}{ Mississippian } \\
\hline mean & 8.3 & 8.0 & 20.2 & 18.4 & 166.6 & 147.3 & 156.1 & 143.3 \\
\hline no. & 49 & 35 & 41 & 27 & 41 & 27 & 62 & 45 \\
\hline
\end{tabular}

${ }_{1}^{1}$ For more extensive data, see Hinton (1981c).

${ }^{2}$ Area of the mandibular fossa (temporal joint surface) was calculated as described in Hinton and Carison (1979). Condylar area was calculated as the product of breadth (maximum distance between the most medial and most lateral points on the articular surfacel and Iength (maximum anterior-posterior distance near the midpoint of the articular surface). Condylar length and breadth are given in millimeters, while condylar area and mandibular fossa area are given in square millimeters. 
over the entire time span from Archaic to Mississippian (McCollough and Faulkner, 1973; Robison, 1978; Shea, 1978; Kline and Crites, 1979). The basic similarity of food utilization with the Archaic is particularly marked for the Woodland (Dragoo, 1976; Cowan, 1978), and may not have altered appreciably from a gastronomic standpoint until the Mississippian. Even so, it could be argued that the observed differences in interproximal wear (and hence, masticatory force) are less the result of what was being eaten as they are how the food was prepared for consumption.

For the Southeastern Indians at the time of European contact (including the likely descendants of the Toqua sample), there are numerous ethnographic accounts of methods of food preparation. All emphasize the fondness of the aboriginal inhabitants of this area for stews, soups, puddings, breads, and various forms of "mush" prepared by long hours of stone boiling or baking in an earth oven (Swanton, 1946; Campbell, 1959; Chiltoskey, 1975; Hudson, 1976). Vegetables were seldom eaten raw (Hudson, 1976:308) and preparation of dried meat or vegetable foods was preceded by careful shredding or grinding in a wooden mortar until a fine consistency was achieved isee Swanton, 1946:352, 361, 371). Moreover, meat and shellfish were apparently cooked for many hours until tender before being consumed (Swanton, 1946:279, 368). Finally, while some nuts and fruits were undoubtedly eaten raw, primary usages of the former included incorporation of ground nuts into puddings and stews lafter the shells had been carefully removed, Swanton, 1946:365), and the conversion by pounding and boiling of nuts into a milky oil which was used in cooking (Chiltoskey, 1975: 238; Hudson, 1976:301).

Although there are no ethnographic accounts for earlier peoples, some indication of the prior preparation given the food consumed can be derived from analyses of paleofecal samples. Large numbers of paleofeces from Late Archaic/Early Woodland contexts found in the Salts Cave/Mammoth Cave area of south-central Kentucky (Watson, 1974) are comprised primarily of hickory nutshell, chenopod and maygrass seeds, and sunflower achenes, together with small bones, rock fragments and bits of charcoal (Marquardt, 1974; Schoenwetter, 1974; Yarnell, 1974). These findings are corroborated by the presence of similar materials in the stomach contents of mummified human remains from the Woodland of Salts Cave (Robbins, 1971). Plant and fruit skin was also found in 15 of 27 paleofeces examined by Marquardt (1974). With regard to the feces from Mammoth and Salts Cave, Yarnell (1977:866) has remarked:

... The seeds in the feces show some evidence of roasting or parching but no evidence of grinding or other preparation before eating. This is consistent with the surprising amount of 'roughage' in the feces including sunflower and sumpweed hulls, small bones, fish scales, and large quantities of hickory nutshell.

In one fecal specimen "an entire small mammal, complete with fur and slightly disarticulated" (Chapman, 1973:125, citing Yarnell, 1969) was found. These data suggest that preparation of vegetable and animal food prior to eating may have been minimal in the Archaic and at least the early Woodland periods, and that ethnographic accounts may be applicable only to the Mississippian (see Chapman, 1973 for similar sentiments).

Information is not plentiful concerning the relationship of food consistency and/or preparation to the amount of occlusal force necessary for its mastication. However, it has been shown that foods differ greatly in their resistance to mastication (Yurkstas and Manly, 1950; Anderson, 1956), with dried and raw fruits and vegetables requiring more chewing cycles and somewhat greater bite forces than cooked vegetables and meat to be reduced to similar particle sizes. In vivo measurements of bone strain in monkeys during mastication of various foods (Hylander, 1979) confirm these data, demonstrating appreciably higher levels of mandibular bone strain for dried and/or fibrous foods and reaching a peak for mastication of plum seeds (see also Weijs and deJongh, 1977). In addition, the cellulose component present in the cell wall of vegetable foods and grasses necessitates additional chewing even for foods that do not require heavy bite forces for reduction (Yurkstas and Manly, 1950; Yurkstas, 1976 cited in Carlsson, 1974). The reduction in particle size thus achieved enhances the digestibility of the food in question (McLeod and Minson, 1969), a desirable result for an animal who lacks the specialized adaptations of molar structure or digestive system for such a diet (Sheine and Kay, 1977). Finally, a number of studies have shown that mastication of tough or fibrous foods is accompanied by greater lateral excursions of the lower jaw 
(Weijs and deJongh, 1977; Byrd et al., 1978; Gibbs et al., 1980), which presumably act to amplify the lateral component of the bite force.

From the above discussion it is hypothesized that a primary cause of the extensive interproximal wear noted in the Archaic sample is the application of large occlusal forces over the prolonged number of chewing cycles needed to masticate properly a rugged diet consisting of seeds, nuts, wild plant foods, and small animals (perhaps unboned). In comparison, the foods of the Mississippian peoples, if we are to judge by ethnographic accounts, would require much less heavy chewing, a circumstance presumably reflected in their reduced interproximal wear in relation to both the Archaic and Woodland. The generally intermediate levels of interproximal wear in the Woodland sample may relate to the introduction of pottery during this time period (Dragoo, 1976). In addition, the adoption of the earth oven, which is common in Tennesee Valley sites by the Middle Woodland (Faulkner and McCollough, 1978) but which is encountered as early as the Terminal Archaic (McCollough, 1973; Chapman, 1973; McCollough and Faulkner, 1973), may have assisted in cooking foods to a consistency requiring less strenuous mastication (as documented ethnographically). The total absence of nutshell in a small $(\mathrm{N}=5)$ sample of paleofeces from the Late Woodland of eastern Kentucky (Cowan, 1978) is suggestive of a change in food preparation or nature of foods consumed, in comparison with the abundant nutshell in feces from the Late Archaic Salts/Mammoth Cave. However, Cowan (1978) has interpreted this absence, together with the presence of bark in all five fecal specimens, as evidence of seasonal nutritional stress. The possibility of nutritional stress has also been suggested for the Late Woodland of the IIlinois Valley, based on lowered survivorship, more frequent tooth enamel defects, and reduced protein intake as compared to Middle Woodland populations of the area (Buikstra, 1977; Cook and Buikstra, 1979). Clearly, additional study of Woodland sites (especially Early and Middle) by both archeologists and physical anthropologists is necessary to elucidate this matter.

\section{Implications for a functional model of interproximal wear}

Although many questions remain, this study has demonstrated that relatively and absolutely larger amounts of interproximal wear occur in human groups whose mode of subsis- tence and/or techniques of food preparation necessitate the habitual application of large occlusal forces during mastication. Although multiple factors undoubtedly play a part in the production of interproximal tooth wear, the results of this study suggest that the magnitude and frequency of applied occlusal forces may be of appreciable importance. Specifically, the data presented here provide support for a model relating interproximal wear facet production to the magnitude and frequency of application of a mesial force vector, which is itself the result of the lateral and vertical components of the bite force acting on mesiallyinclined tooth crowns. A further point relevant to this model may be noted by inspection of mean interproximal wear stratified by occlusal wear level as presented in Table 2. In all three samples, the M1M2 facet breadths are in most instances larger than the P2M1 facet breadths, when compared at the same level of occlusal wear. This disparity is most pronounced in the Archaic sample. Within groups, attainment of the same level of occlusal wear is presumably indicative of similar amounts of time under application of the mesial force vector from teeth distal to the tooth in question. It is possible that the larger mean facet breadth for M1M2 is due to the greater angulation of the M2 roots in the mesial direction as compared to the angulation of the $M 1$ roots (average of about $15^{\circ}$ from the vertical for lower M1, $27^{\circ}$ for lower M2; data from Kraus et al., 1969). Thus, within groups, the difference in angulation should produce, for the same bite force, a larger mesial force vector at the junction of M1 and M2 than at the junction of P2 and M1. Between groups, the difference in angulation would tend to amplify the effect of any intergroup differences in bite force on the production of a mesial force vector, so that the disparity between P2M1 and M1M2 facet breadth should be (and is) largest in the Archaic sample. A similar comparison of P2M1 and M1M2 facet breadths in maxillary molars should comprise a test of this suggestion, since the difference in root angulation is much less pronounced in these teeth $\left(12^{\circ}\right.$ for upper M1 and $10^{\circ}$ for upper M2; data from Kraus et al., 1969).

\section{ACKNOWLEDGMENTS}

I am grateful to Dr. Paul Parmalee, Director, McClung Museum, University of Tennessee at Knoxville for access to the collections utilized in this study. Thanks are also due Patricia Hin. ton for advice on statistical processing of the data and Dr. Fred Smith for reading and commenting on the manuscript. In addition, I 
would like to express my appreciation to $B$. Holly Smith for her collaboration in development of the coding system for occlusal tooth wear. This paper has also benefitted from comments provided by two anonymous reviewers. This research was supported by a Hilton A. Smith Postdoctoral Fellowship in the Department of Anthropology, The University of Tennessee, Knoxville.

\section{LITERATURE CITED}

Anderson, D J (1956) Measurement of stresses in mastication. J. Dent. Res. 35:664-673.

Barber, C G, Green, L J, and Cox, G J (1963) Effects of the physical consistency of diet on the condylar growth of the rat mandible. J. Dent. Res. 42:848-851.

Bowen. W R (1975) Late Archaic Subsistence and Settlement in the Western Tennessee Valley: A Reevaluation. Unpublished M. A. Thesis, University of Tennessee, Knoxville.

Bowen, W R (1979) The Late Archaic in the Upper Duck River Valley. Tenn. Anthrop. 4:140-159.

Brodie, A G (1934) The significance of tooth form. Angle Orthodont. 4:335-350.

Buikstra, J E (1977) Biocultural dimensions of archaeological study: a regional perspective. In $\mathrm{R} \mathrm{L}$ Blakeley (ed): Biocultural Adaptation in Prehistoric America. Southern Anthropological Society Proceedings No. 11. Athens: The University of Georgia Press, pp. 67-84.

Byrd, K E, Milberg, D J, and Luschei, E S (1978) Human and macaque mastication: a quantitative study. J. Dent. Res. 57:834-843.

Campbell, $T$ N (1959) Choctaw subsistence: ethnographic notes from the Linceum manuscript. Florida Anthrop. 12:9-24.

Carlson, D S, McNamara. J A Jr., and Jaul, D H (1978) Histological analysis of the growth of the mandibular condyle in the rhesus monkey (Macaca mulatta). Am. J. Anat. 151:103-118.

Carlsson, G E (1974) Bite force and chewing efficiency. In Y Kawamura (ed): Frontiers of Oral Physiology, Vol. I. Basel: Karger, pp. 265-292.

Chapman, J (1973) The Icehouse Bottom Site-40MR23. Report of Investigations No. 13, Department of Anthropology, University of Tennessee, Knoxville.

Chiltoskey, M U (1975) Cherokee Indian foods. In ML Arnott (ed): Gastronomy: The Anthropology of Food Habits. The Hague: Mouton, pp. 235-244.

Cook, D C and Buíkstra, J E (1979) Health and differential survival in prehistoric populations: prenatal dental defects. Am. J. Phys. Anthrop. 51:649-664.

Cowan. C W (1978) Seasonal nutritional stress in a Late Woodland population: suggestions from some Eastern Kentucky coprolites. Tenn. Anthrop. 3:117-128.

Crites, G D (1978) Plant food utilization patterns during the Middle Woodland Owl Hollow phase in Tennessee: a preliminary report. Tenn. Anthrop. 3:79-92.

Dempster, W T, Adams, W J, and Duddles, R A (1963) Arrangement in the jaws of the roots of the teeth. J. Am. Dent. Assoc. 67:779-801

Dewell, B F (1949) Clinical observations on the axial inclination of teeth. Am. J. Orthodont. 35:98-115.

Dragoo, D W (1976) Some aspects of Eastern North American prehistory: a review. 1975. Am. Antiq. 41:3-27.

Faulkner, C H (1977) Eoff I site (40CF 32). In C H Faulkner and MCR McCollough (eds): Fourth Report of the Normandy Archaeological Project. Report of Investigations No. 19, Department of Anthropology, University of Tennessee, Knoxville, pp. 65-278.
Faulkner, C H, Corkran, M H, and Parmalee, P W (1976) Re port on floral and faunal remains recovered in $1972 \mathrm{ex}$ cavations on the Banks III site (40CF 108). In MCR McCollough and C H Faulkner (eds): Third Report of the Normandy Archaeological Project. Report of Investigations No, 16, Department of Anthropology, University of Tennessee, Knoxville, pp. 217-238

Faulkner, C H and McCollough, M C R (1978) Fifth Report of the Normandy Archaeological Project. Report of Investigations No. 20, Department of Anthropology. University of Tennessee, Knoxville.

Gibbs, C H. Lundeen, H C, Mahan, P E, and Lupkiewicz, S $M$ (1980) Movements of the molar teeth and the mandibular condyles during chewing. J. Dent. Res. 59, Spec. Iss. B:915 (abstract).

Goose, D H (1963) Dental measurement: an assessment of its value in anthropological studies. In D R Brothwell (ed) Dental Anthropology. New York: Pergamon, pp. 125-148.

Graf, H (1975) Occlusal forces during function. In N Rowe (ed): Occlusion: Research in Form and Function. Universi ty of Michigan School of Dentistry, Ann Arbor, pp. 112-119.

Iinton, R J (1981a) Changes in articular eminence morphology with dental function. Am. J. Phys. Anthrop., in press.

Hinton, R J (1981b) Form and patterning of anterior tooth wear among aboriginal human groups. Am. J. Phys. Anthrop., in press.

Hinton, R J (1981c) Temporomandibular joint size adaptations in prehistoric Tennessee Indians. Tenn. Anthrop., in press.

Hinton, R J and Carlson, D S (1979) Temporal changes in human temporomandibular joint size and shape. Am. J. Phys. Anthrop. 50:325-334.

Hinton, R J. Smith, M O, and Smith, F H (1980) Tooth size changes in prehistoric Tennessee Indians. Human Biology 52:229-245

Hudson, C (1976) The Southeastern Indians. Knoxville: The University of Tennessee Press.

Hylander, W L (1979) Mandibular function in Galago cras sicaudatus and Macaca fascicularis: an in vivo approach to stress analysis of the mandible. J. Morph. 159:253-296.

Kline, G W and Crites, G D (1979) Paleothnobotany of the Duck's Nest site: early Mississippian plant utilization in the Eastern Highland Rim. Tenn. Anthrop. 4:82-100.

Kraus, B S, Jordan, R E, and Abrams, L (1969) Dental Anatomy and Occlusion. Baltimore: The Williams and Wilkins Company.

Lavelle, C L B (1970) Analysis of attrition in adult human molars. J. Dent. Res. 49:822-828.

Lewis, T M N and Kneberg, M (1946) Hiwassee Island. Knoxville: The University of Tennessee Press.

Lewis, T M N and Kneberg, M (1959) The Archaic culture in the Middle South. Am. Antiq. 25:161-183.

Lewis, T M N and Lewis, M K (1961) Eva: An Archaic Site Knoxville: The University of Tennessee Press.

Magennis, A L (1977) Middle and Late Archaic Mortuary Patterning: An Example from the Western Tennessee Valley. Unpublished M. A. Thesis, University of Tennessee, Knoxville.

Marquardt, W H (1974) A statistical analysis of constituents in human paleofecal specimens from Mammoth Cave. In P J Watson (ed): Archaeology of the Mammoth Cave Area. New York: Academic Press, pp. 193-202.

McCollough, M C R (1973) Supplementary chronology for the Higgs site (40L,045), with an assessment of terminal Archaic living and structure floors. Tenn. Arch. 29:63-68.

McCollough, M C R and Faulkner, C H (1973) Excavation of the Higgs and Doughty Sites: I-75 Salvage Archaeology. Tennessee Archaeological Society Miscellaneous Paper No. 12. 
MeLeod, M N and Minson, D J (1969) Sources of variation in the in vivo digestibility of tropical grasses. J. Brit. Grassland Soc. 24:244-253.

McNamara, J A Jr, and Carison, D S (1979) Quantitative analysis of temporomandibular joint adaptations to protrusive function. Am. J. Orthodont. 76:593-611.

Molnar, S (1968) Some Functional Interpretations of Tooth Wear in Prehistoric and Modern Man. Unpublished doctoral dissertation, University of California, Santa Barbara.

Molnar, S (1971a) Sex, age, and tooth position as factors in the production of tooth wear. Am. Antiq. 36:182-188.

Molnar, S (1971b) Human tooth wear, tooth function, and cultural variability. Am. J. Phys. Anthrop. 34:175-190.

Moore, W J (1965) Masticatory function and skull growth. J. Zool. 146:123-131.

Moss, J P and Picton, D C A (1967) Experimental mesial drift in adult monkeys (Macaca irus). Arch. Oral Biol. 12:1313-1320.

Moss. J P and Picton. D C A (1970) Mesial drift of teeth in aduit male monkeys (Macaca irus) when forces from the cheeks and tongue have been eliminated. Arch. Oral Biol. 15:979-986.

Moyers, R E (1973) Handbook of Orthodontics. Third edition. Chicago: Year Book Medical Publishers.

Neter, J and Wasserman, W (1974) Applied Linear Statistical Models. Homewood, Illinois: Richard D. Irwin. Inc.

O'Leary, T J, Rudd, K D, Nabers, C L, and Stumpf, A J Jr. (1967) Effect of a "tube-type" diet and stress inducing conditions on tooth mobility. J. Periodont. 38:222-226.

Parham. K E (n.d.) The Physical Anthropology of the Dallas People from Toqua (40MR6). M. A. Thesis in preparation, Department of Anthropology. University of Tennessee, Knoxville.

Picton. D C A (1962) Tilting movements of teeth during biting. Arch. Oral Biol. 7:151-159.

Picton, D C A (1964) Some implications of normal tooth mobility during mastication. Arch. Oral Biol. 9:151-159.

Picton, D C A and Moss. J P (1973) The effect of trauma to the trans-septal fibre system on mesial drift of the teeth in monkeys. Arch. Oral Biol. 18:565-573.

Picton, D C A and Moss, J P (1974) The relationship between the angulation of the roots and the rate of approximal drift of cheek teeth in adult monkeys. Br. J. Orthodont. $1: 105-110$.

Picton, D C A and Moss, J P(1980) The effect on approximal drift of altering the horizontal component of biting force in adult monkeys (Macaca irus). Arch. Oral Biol. $25: 45-48$.

Robbins, L M (1971) A Woodland "mummy" from Salt's Cave, Kentucky. Am. Antiq. 36:200-206.

Robison, N D (1978) A zooarchaeological analysis of the Mississippian faunal remains from the Normandy reservoir. In C H Faulkner and M C R McCollough (eds): Fifth Report of the Normandy Archaeological Project. Report of Investigations No. 20. Department of Anthropology. University of Tennessee, Knoxville, pp. 498-595.

Schoen wetter, J (1974) Pollen analysis of human paleofeces from Upper Salts Cave. In P J Watson (ed): Archaeology of the Mammoth Cave Area. New York: Academic Press, pp. $49-58$.

Schroedl, GF and Polhemus, RF (1977) A summary and preliminary interpretation of archaeological investigations at the Toqua site (40MR6). Report submitted to the National Park Service.

Shea, A B (1978) An analysis of plant remains from the Middle Woodland and Mississippian components on the Banks V site and a paleoethnobotanical study of the native flora of the Upper Duck River Valley. In $\mathrm{C} \mathrm{H}$
Faulkner and M C R McCollough (eds): Fifth Report of the Normandy Archaeological Project. Report of Investigations No. 20, Department of Anthropology, University of Tennessee, Knoxville, pp. 596-699.

Sheine, W S and Kay, R F (1977) An analysis of chewed food particle size and its relationship to molar structure in the primates Cheirogaleus medius and Galago senegalensis and the Insectivoran Tupaia glis. Am. J. Phys. Anthrop. 47:15-20.

Simon, M R (1977) The role of compressive forces in the normal maturation of the condylar cartilage in the rat. Acta Anat. 97:351-360.

Smith, F H, Smith, M O, and Hinton, R J (1980) Evolution of tooth size in the inhabitants of the prehistoric Tennessee Valley. In P Willey and F H Smith (eds): Skeletal Biology of Aboriginal Populations in the Southeastern United States. Miscellaneous Paper No. 5, Tennessee Anthropological Association, University of Tennessee. Knoxville, pp. 81-103.

Swanton, J R (1946) The Indians of the Southeastern United States. Bur. Am. Ethnol. Bull. 137.

Taylor, R M S (1963) Cause and effect of wear of teeth. Acta Anat. 53:97-157.

Van Beek, H and Fidler, V J (1977) An experimental study of the effect of functional occlusion on mesial tooth migration in macaque monkeys. Arch. Oral Biol. 22:269-271.

Walker, P L (1978) A quantitative analysis of dental attrition rates in the Santa Barbara Channel Area. Am. J. Phys. Anthrop. 48:101-106.

Ward, S (1974) Form and Function in Primate Jaw Mechanics: An Experimental Analysis. Unpublished doctoral dissertation, Washington University, St. Louis.

Watson, P J (1974) Prehistoric horticulturalists. In P J Watson (ed): Archaeology of the Mammoth Cave Area. New York: Academic Press, pp. 233-238.

Watt, P G and Williams, H M (1951) The effects of the physical consistency of food on the growth and development of the mandible and maxilla of the rat. Am. J. Orthodont. 37:895-928

Weijs, W A and deJongh, H J (1977) Strain in mandibular alveolar bone during mastication in the rabbit. Arch. Oral Biol. 22:667-675.

White, T D (1977) The Anterior Mandibular Corpus of Early African Hominidae: Functional Significance of Size and Shape. Unpublished doctoral dissertation, University of Michigan, Ann Arbor.

Wolpoff, M H (1971) Interstitial wear. Am. J. Phys. An throp. 34:205-228.

Wolpoff, M H (1975) Some aspects of human mandibular evolution. In J A McNamara Jr. (ed): Determinants of Mandibular Form and Growth. Monograph Number 4, Craniofacial Growth Series. Ann Arbor: Center for Human Growth and Development, pp. 1-65.

Yarnell, R A (1969) Contents of human paleofeces. In P J Watson (ed): The Prehistory of Salts Cave, Kentucky. Report of Investigations No. 16, Illinois State Museum, Springfield.

Yarnell, R A (1974) Plant food and cultivation of the Salts Cavers. In P J Watson (ed): Archaeology of the Mammoth Cave Area. New York: Academic Press, pp. 113-122.

Yarnell, R A (1977) Native plant husbandry north of Mex ico. In CA Reed (ed): Origins of Agriculture. The Hague Mouton, pp. 861-875

Yurkstas, A (1965) The masticatory act. J. Prosthet. Dent. 15:248-260.

Yurkstas, A and Manly, R S (1950) Value of different foods in estimating masticatory ability. J. Appl. Physiol 3:45-53. 